\title{
SEASONAL PHYTOPLANKTON COMMUNITY PATTERNS AND INFLUENCING FACTORS IN FISH-MUSSEL SYSTEMS
}

\author{
HU, B.J. ${ }^{1,2}-$ HUANG, Y.Y. ${ }^{1}-$ WU, L.Z. ${ }^{1}-$ QIN, H.M. $.^{3,4^{*}}-$ HONG, Y.J. ${ }^{1,2 *}$ \\ ${ }^{1}$ School of Life Science, Nanchang University, Nanchang, Jiangxi Province, China \\ ${ }^{2}$ Jiangxi Province Key Laboratory of Aquatic Animal Resources and Utilization, Nanchang \\ University, Nanchang, Jiangxi Province, China \\ ${ }^{3}$ Jiangxi Province Key Laboratory of Watershed Ecosystem Change and Biodiversity, Nanchang \\ University, Nanchang, Jiangxi Province, China \\ ${ }^{4}$ School of Life Sciences, Qufu Normal University, Qufu, Shandong Province, China \\ *Corresponding author \\ e-mail: qinhaiming@qfnu.edu.cn, yjhong@ncu.edu.cn \\ (Received 24 $4^{\text {th }}$ Oct 2019; accepted $12^{\text {th }}$ Mar 2020)
}

\begin{abstract}
The rapid pearl farming industry causes environmental pollution to aquatic ecosystems. However, fish-mussel systems with highly productive, profitable and environment-friendly characteristics are appropriate aquaculture practices under the current polluted state of the environment in China. Phytoplankton are excellent indicators and play indispensable roles in maintaining the stability of a freshwater ecosystem. Therefore, samples were seasonally collected determine the seasonal phytoplankton community dynamics and potential driving factors in three subtropical reservoirs with integrated fish-mussel aquaculture. All water physicochemical parameters varied seasonally, and water quality had a trend of eutrophication. A total of 189 species were identified, among which Chlorophyta (83 species) dominated in species richness. Cyanophyta, in particular remained to be highly abundant (57.53\% of the total seasonal biomass). The NMDS analysis indicated that summer was an independent branch. The CCA analysis and Spearman rank correlation analysis suggested that water temperature might be the main abiotic factor. Furthermore, $\mathrm{pH}$, conductivity, DO, chlorophyll, TC and TN also significantly affected the community. The aquaculture enhanced the similarity in community structure which have happened due to predation pressure. The present study also identified the potential influences caused by the integrated fish-mussel aquaculture on phytoplankton seasonal succession, bringing some guidance to protect the reservoir ecosystem.
\end{abstract}

Keywords: phytoplankton community structure, seasonal variation, reservoir ecosystem, predation pressure

\section{Introduction}

Large scale freshwater pearl production began in the 1960s in China, and accounted for $95 \%$ of the freshwater pearl production of the world (Li, 2007), making China the most crucial contributor to the world's freshwater pearl production. However, rapid development of freshwater pearl farming causes environmental pollution. The traditional industry is facing urgent transformation and upgrading. Therefore, we have formed a fish-mussel system aiming at aquaculture water, "One Water, Two Treatments; One Mussel, Two Functions": the breeding of mussels and fish bring about the effective governance of aquaculture water, and mussels produce clean water and generate pearls (http://www.pyhfish.com/article-821-1.html). Hyriopsis schlegelii $(H$. schlegelii) was the very important producer of freshwater pearl in China due to its better quality of pearls, pretty breeding technology, and simple artificial pearl producing 
operation (Peng et al., 2012; He et al., 2013). Several aspects fundamentally accounted for the success of the freshwater pearl industry. Species with superduper performance of pearl production and continuously optimized culture models have contributed to the increasing annual freshwater pearl production, from approximately 3.5 tons during the period of 1958-1971 to approximately 4,448.34 tons during the period of 2002-2007 (Bai et al., 2014).

It is well known that freshwater pearl mussel, bighead carp and silver carp are aquaculture animals with high economic value, mainly grazing plankton. Among these culture models, integrated fish-mussel aquaculture, which cultures some filter fish, such as silver carp and bighead carp, into the water body with mussels, was practical, and improved water quality deterioration (Neori et al., 2004). Meanwhile, the concentrations of nitrogen, phosphorus and organics decreased in a planktivorous fish-mussel system, with an increase in the yield and growth of $H$. cumingii (Wang et al., 2009). Polyculture could improve the utilization efficiency of nutrients and water quality and increase yield, which has been widely applied for aquaculture (Milstein, 1992; Troell et al., 2003; Schneider et al., 2005). Water-quality deterioration and eutrophication might occur as a result of the significantly increased concentrations of nitrogen and phosphorus, which lead to cyanobacterial blooms, and bring negative impacts on photosynthesis in submerged plants on the account of blocking light (Hauxwell et al., 2001). This would further lessen the dissolved oxygen and might destroy aquatic ecosystems (Guo et al., 2009). However, various studies have focused on the optimization of the aquaculture production models, which were mainly on the integrated combination and management regimes. Researches with regard to production efficiency under the combination of various species were conducted by Tang et al. (2015) and Yan et al. (2009). Zheng et al. (2018) conducted a preliminary study on optimizing water quality and bacterial community in fish-mussel systems by regulating the $\mathrm{C} / \mathrm{N}$ ratio. However, little attention was attached to the impact on the water ecosystem (including phytoplankton distribution, composition, etc.) caused by integrated fish-mussel aquaculture, even though phytoplankton was the most basic and nuclear primary producer, and contributed high effects on the dynamic equilibrium and relative stabilization. Furthermore, diatoms even affected the atmospheric $\mathrm{CO}_{2}$ levels, considering that phytoplankton occupies a crucial position in the water ecosystem (Meyer et al., 2017; Leblanc et al., 2018; Milligan and Morel, 2012).

In particular, the diversity and richness of species generally exist in subtropical reservoirs, and Connell (1978) indicated determining factors that maintain the diversity in an ecosystem is crucial. Phytoplankton, as a kind of excellent bait for aquatic animals, and helps to better manage and maintain the sustainable utilization of water resources. Degefu et al. (2011) evaluated the potential impact of Nile Tilapia cage culture on water quality, and the zooplankton and phytoplankton community. It was indicated that cage culture enhanced the ammonium nitrogen levels and Cyanobacteria as a dominator, contributing $84 \%$ of the total phytoplankton abundance. In addition, And (1999) discovered that water quality deteriorated, and that the diversity and abundance of phytoplankton changed in shrimp ponds. Furthermore, Nile tilapia and Macrobrachium rosenbergii poluculture reduced the phytoplankton biovolume, and afternoon $\mathrm{pH}$ level was lower, when compared to prawn monoculture (Danaher et al., 2007). Rainbow trout cage cultures decreased the dissolved oxygen, and made Daphnia $s p$. dominant species (90\% of the zooplankton), according to a study (Cornel and Whoriskey, 1993). Nevertheless, studies on the cumulative effect of natural- and 
human-induced processes on environment factors and phytoplankton in $\mathrm{H}$. schlegeliibighead carp and silver carp systems remains scarce. It is expected that the seasonal pattern of phytoplankton could be influenced by fish-mussel polyculture. In order to investigate the hypothesis, the seasonal investigation of phytoplankton was conducted from August 2017 to March 2018 in three sub-tropic reservoirs with integrated fishmussel aquaculture. The specific aims were as follows: (1) to determine the seasonal variation and succession rules in the phytoplankton community, and the potential driving factors; (2) to clarify whether the fish-mussel polyculture might induce the similarity of phytoplankton community between seasons.

\section{Materials and methods}

\section{Experimental design}

Duchang county is the most important freshwater pearl production region in China. Experiments were carried out in Dagang (DG, with fish feed), Zhouxi (ZX, with biofeeding) and Hetang (HT, with organic fertilizer) in reservoirs located in Duchang county. The three reservoirs are about 8 acers and $10 \mathrm{~m}$ deep. And these reservoirs were cleaned and sterilized by lime prior to experiments. The conditions and the placing of plots were similar for these three experimental plots, with alike water supply and husbandry management. Bighead carps and silver carps were left to swim freely, and $\mathrm{H}$. schlegelii were hung in the water column at approximately $50 \mathrm{~cm}$ below the water surface ( 8 mussels in each water column, 600 columns in each acer). The whole aquatic organisms were purchased from local commercial farms.

\section{Sampling design}

Phytoplankton were seasonally sampled (spring $=$ March, summer $=$ August, autumn $=$ October, and winter $=$ December) at three points in three reservoirs from August 2017 to March 2018. The sampling points were set according to the occupation area of each reservoir, and sampling was performed for three times for each point (Fig. 1). At approximately $100 \mathrm{~cm}$ below the water surface, $10 \mathrm{~L}$ of mixed water were collected using a 10-L modified Schindler-Patalas sampler. A plankton net with a mesh size width of $64 \mu \mathrm{m}$ was used to filter the water, and phytoplankton were collected from the end of the net and placed into a 10-ml plastic tubing with 1\% Lugol's solution. Counting and identifying were conducted under a microscope (Olympus SZ61, Japan; Olympus CX23, Korea). The biomass of the phytoplankton (wet weight) was calculated, according to the study conducted by Zhang and Huang (1991). For the physico-chemical parameters, WT, pH, conductivity (Cond), dissolved oxygen (DO), turbidity (Turb) and Chl-a were measured for three times in situ using a Multifunction Water Quality Monitor (YSI 6600 V2, USA). Then, $25 \mathrm{ml}$ of water was collected from each sampling point with two replications. The samples were storing at $-20{ }^{\circ} \mathrm{C}$ in a laboratory, and the total nitrogen (TN) and total carbon (TC) were determined using a carbon-nitrogen analyzer.

The $1 \mathrm{~L}$ of collected water was filtered through a Whatman GF/F fiberglass filter membrane (burned at $450{ }^{\circ} \mathrm{C}$ for $2 \mathrm{~h}$ before removing the organic matter), which had a diameter of $25 \mathrm{~mm}$. Then, the membrane was dried under $60{ }^{\circ} \mathrm{C}$ for $48 \mathrm{~h}$, and allowed to cool after weighing in the dryer. The dried GF/F fiberglass filter membrane was burned at $450{ }^{\circ} \mathrm{C}$ for $2 \mathrm{~h}$ and weighted (ash weight after burning) again after cooling. The 
content of the particulate organic matter in the water sample was calculated according to the weight of the blank filter membrane, the dried sample filter membrane, and lost weight after burning, and the volume of the water sample.

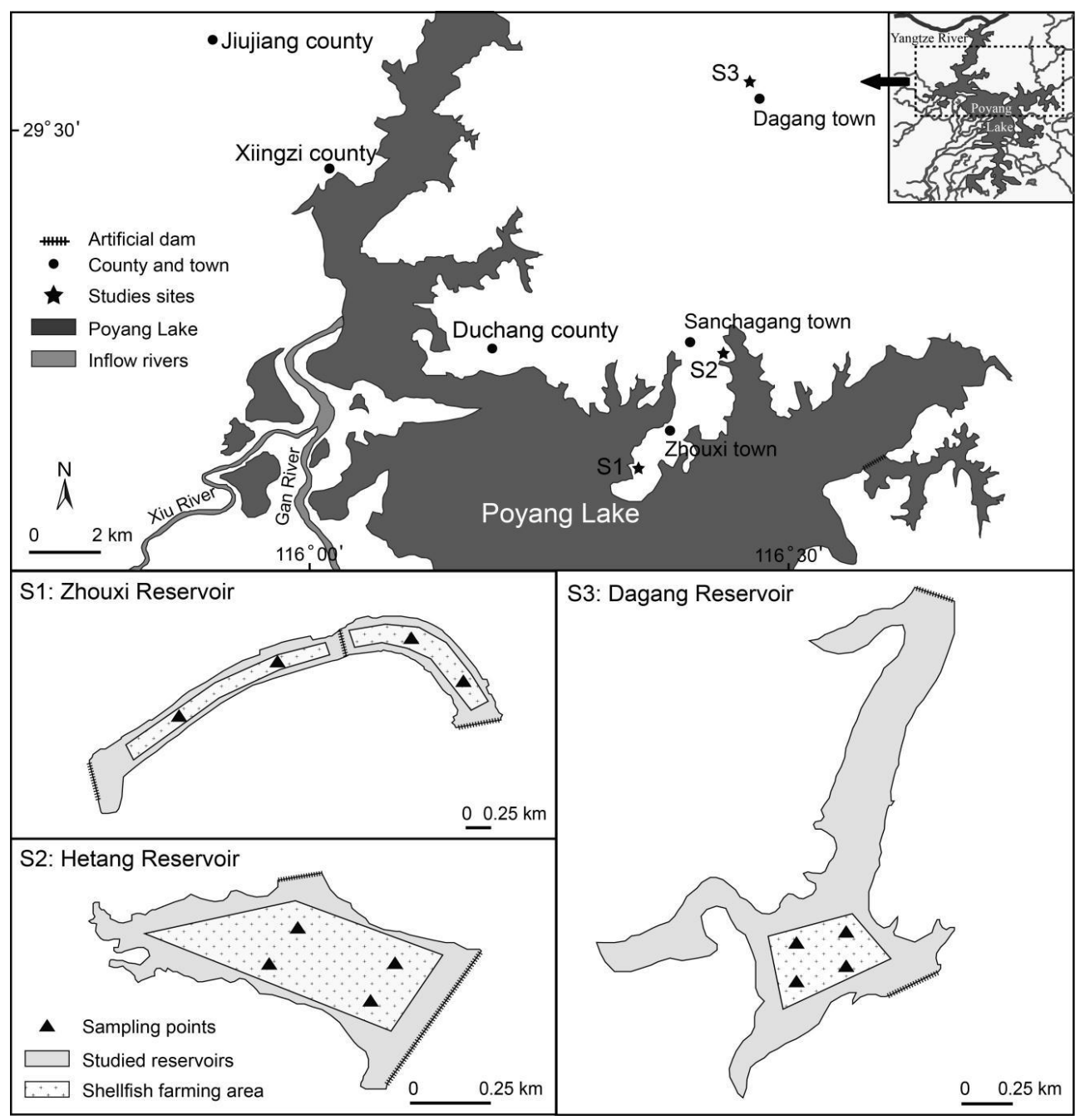

Figure 1. Location of the studied sites and sampling points in the $D G, H T$ and $Z X$ reservoirs

\section{Statistical analysis}

The Shannon-Weiner diversity index (H'), Margalef richness index (D) and Pielou evenness index ( $\mathrm{J}$ ') were calculated, as follows:

$$
\begin{gathered}
\mathrm{H}^{\prime}=-\sum \mathrm{Pi} \ln (\mathrm{Pi}) \\
\mathrm{D}=(\mathrm{S}-1) / \ln \mathrm{N} \\
\mathrm{J}^{\prime}=\mathrm{H}^{\prime} / \ln \mathrm{S}
\end{gathered}
$$

where $\mathrm{Pi}$ is the proportion of $\mathrm{i}$ species densities in the total phytoplankton density, and $\mathrm{S}$ is species number.

The dominance index was as follows:

$$
\mathrm{Y}=\mathrm{ni} \times \mathrm{fi} / \mathrm{N}
$$


where ni represents the number, fi represents the occurrence frequency of $i$ species, and $\mathrm{N}$ represents the whole numbers. The species was deemed as dominant species when $\mathrm{Y} \geq 0.02$.

The seasonal variations in water physico-chemical parameters (i.e. WT, $\mathrm{pH}$, Cond, DO, Turb and Chl-a), TN, TC and phytoplankton parameters (i.e. biomass, H', D and J') were examined by one-way ANOVA, and the differences were further tested with LSD multiple comparison under various treatments. Spearman rank correlation analysis was performed to identify the correlation among physico-chemical parameters, TC, TN and the biomass of phytoplankton. $\mathrm{P}<0.05$ was the significant level. The seasonal variation in phytoplankton community structure was determined by NMDS analysis with the biomass data of dominant species using a ranked similarity matrix based on Bray-Curtis similarity measures.

A detrended correspondence analysis on species data was performed prior to the analysis of species-environmental correlation, and revealed the longest gradient length of 4.9, indicating that the Canonical correspondence analysis was applicable. Therefore, the correlation between water physico-chemical parameters and phytoplankton dominant species was examined with CCA, and the significance was determined by the Monte Carlo test using the Canoco for Windows 4.5 software (Microcomputer Power, Ithaca, USA). Then, one-way ANOVA, LSD multiple comparison and Spearman rank correlation analysis were performed with SPSS (version 22.0; IBM Corp., Armonk, USA). NMDS ordination analysis was performed with the PRIMER 5 computer package (Clarke and Warwick, 1994).

\section{Results}

\section{Physico-chemical parameters}

The one-way ANOVA indicated that all water physico-chemical parameters differed seasonally. The fluctuation rule for water temperature was that it increased from spring, reaching a maximum $( \pm \mathrm{SE})$ of $30.93 \pm 0.22{ }^{\circ} \mathrm{C}$ in summer, and continuously dropped from autumn to winter, reaching a minimum of $4.77 \pm 0.31{ }^{\circ} \mathrm{C}$ (Table 1). A similar fluctuation rule was also observed in $\mathrm{pH}$, conductivity and turbidity. In general, the water was characterized by alkalinity, ranging from $7.86 \pm 0.04$ to $8.80 \pm 0.05$. The DO concentrations ranged from $8.98 \pm 0.11 \mathrm{mg} / \mathrm{L}$ in winter to $10.45 \pm 0.17 \mathrm{mg} / \mathrm{L}$ in spring, indicating that a higher oxygen capacity occurred in spring. Conductivity and turbidity ranged from $101.61 \pm 30.20$ to $1,342.28 \pm 85.87 \mu \mathrm{S} / \mathrm{cm}$, and from $5.26 \pm 0.69$ to $14.48 \pm 2.65$ NTU, respectively. Furthermore, chlorophyll-a values and total carbon, which included total organic carbon and total inorganic carbon, peaked in autumn $(24.64 \pm 2.12 \mu \mathrm{g} / \mathrm{L}$ and $9.75 \pm 0.62 \mathrm{mg} / \mathrm{L}$, respectively), followed by a gradual decrease, reaching a minimum value in winter $(2.39 \pm 0.11 \mu \mathrm{g} / \mathrm{L}$ and $6.16 \pm 0.35 \mathrm{mg} / \mathrm{L}$, respectively). On the contrary, TN had a minimum of $0.63 \pm 0.03 \mathrm{mg} / \mathrm{L}$ in autumn, but peaked to $1.10 \pm 0.1 \mathrm{mg} / \mathrm{L}$ in summer.

\section{Species composition}

A total of 189 species were identified and belonged to seven groups: Cyanophyta,

Chlorophyta, Bacillariophyta, Xanthophyta, Pyrrophyta, Euglenophyta and Chrysophyta. Chlorophyta was deemed as the most abundant group, which had 83 species (approximately $43.92 \%$ of the total species number), followed by Cyanophyta 
(59 species) and Bacillariophyta (25 species). The others, such as Xanthophyta, Pyrrophyta, Euglenophyta and Chrysophyta, were sporadically recorded (Table Al in the Appendix).

Table 1. Mean values ( \pm standard error) of the physicochemical factors

\begin{tabular}{c|c|c|c|c|c|c}
\hline & Spring & Summer & Autumn & Winter & F & P \\
\hline WT $\left({ }^{\circ} \mathrm{C}\right)$ & $14.68 \pm 0.09^{\mathrm{b}}$ & $30.93 \pm 0.22^{\mathrm{d}}$ & $21.93 \pm 0.09^{\mathrm{c}}$ & $4.77 \pm 0.31^{\mathrm{a}}$ & 3002.41 & $<0.001$ \\
Cond $(\mu \mathrm{S} / \mathrm{cm})$ & $911.06 \pm 61.25^{\mathrm{b}}$ & $1342.28 \pm 85.87^{\mathrm{d}}$ & $1107.28 \pm 74.13^{\mathrm{c}}$ & $101.61 \pm 30.20^{\mathrm{a}}$ & 66.269 & $<0.001$ \\
pH & $7.87 \pm 0.05^{\mathrm{a}}$ & $8.80 \pm 0.05^{\mathrm{b}}$ & $8.05 \pm 0.13^{\mathrm{a}}$ & $7.86 \pm 0.04^{\mathrm{a}}$ & 32.149 & $<0.001$ \\
Turb (NTU) & $7.80 \pm 1.64^{\mathrm{ab}}$ & $14.48 \pm 2.65^{\mathrm{c}}$ & $11.27 \pm 2.22^{\mathrm{bc}}$ & $5.26 \pm 0.69^{\mathrm{a}}$ & 4.294 & 0.008 \\
DO (mg/L) & $10.45 \pm 0.17^{\mathrm{b}}$ & $9.19 \pm 0.20^{\mathrm{a}}$ & $9.69 \pm 0.40^{\mathrm{a}}$ & $8.98 \pm 0.11^{\mathrm{a}}$ & 7.038 & $<0.001$ \\
Chl-a $(\mu \mathrm{g} / \mathrm{L})$ & $17.17 \pm 2.14^{\mathrm{c}}$ & $9.03 \pm 1.25^{\mathrm{b}}$ & $24.64 \pm 2.12^{\mathrm{d}}$ & $2.39 \pm 0.11^{\mathrm{a}}$ & 35.122 & $<0.001$ \\
TC $(\mathrm{mg} / \mathrm{L})$ & $7.07 \pm 0.29^{\mathrm{ab}}$ & $7.98 \pm 0.68^{\mathrm{b}}$ & $9.75 \pm 0.62^{\mathrm{c}}$ & $6.16 \pm 0.35^{\mathrm{a}}$ & 9.004 & $<0.001$ \\
TN $(\mathrm{mg} / \mathrm{L})$ & $1.05 \pm 0.14^{\mathrm{b}}$ & $1.10 \pm 0.15^{\mathrm{b}}$ & $0.63 \pm 0.03^{\mathrm{a}}$ & $0.87 \pm 0.07^{\mathrm{ab}}$ & 3.684 & 0.016 \\
\hline
\end{tabular}

The phytoplankton composition changed with the seasons and sites, which indicate a trend, in which taxa numbers gradually increased from spring to autumn, reached a peak period, and decreased (Fig. 2). A total of 112 species were recorded in spring, with a minimum (29) in DG, and these were similar in HT (42) and ZX (41). A total of 153 and 120 species were observed in summer and winter, respectively. In general, the taxa numbers exhibited a slight fluctuation of approximately 50 (in summer) and 40 (in winter) in three reservoirs. A total of 180 species were captured in autumn, with the minimum (50), and the number of taxa in HT (67) were slightly higher than those in ZX (63). In addition, 4, 6 and 5 species remained as co-existing species from spring to winter in DG, HT and ZX, respectively, and these mainly comprised of Bacillariophyta, in addition to Chlorophyta and Cyanophyta.

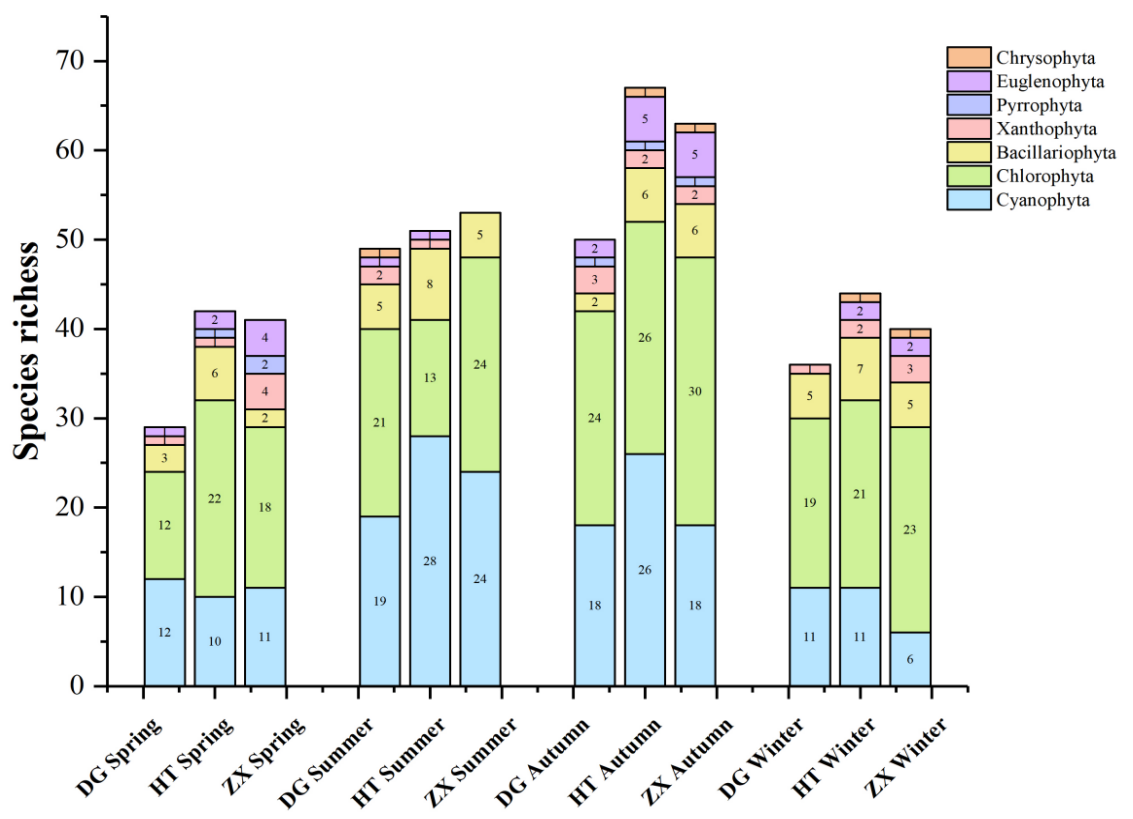

Figure 2. Seasonal species richness of each phytoplankton group in the DG, HT and ZX reservoirs from August 2017 to March 2018 


\section{Dominant species}

The number of dominant species were 9, 9 and 12 for DG, HT and ZX throughout the sampling period. Furthermore, 9, 3, 6 and 7 dominant species occurred from spring to winter. These dominant species changed with the seasons. Microcystis pallida dominated in spring and summer. Synechocystis aquatilis and Ulothrix tenerrima were the dominant species in summer and winter, and in spring and winter, respectively. Microspora stagnorum dominated the four seasons, except for summer, and merely Chlorella pyrenoidosa was the dominant species from spring to winter.

The highest dominance was marked by Jaaginema angustissimum in spring, Synechocystis aquatilis in summer, Microcystis minutissima in autumn, and Oscillatoria tenuis in winter, with a dominance index of $0.57,0.93,0.25$ and 0.20 , respectively.

\section{Biomass of phytoplankton}

A similar trend was found in the seasonal dynamics of phytoplankton biomass. There was a relatively low biomass in spring, which peaked in summer on account of the outbreak of Cyanophyta, and progressively decreased to the minimum in winter. The fluctuation rule was consistent with the seasonal dynamics of Cyanophyta. Cyanophyta contributed to the seasonal total biomass, which ranged from $17.80 \%$ (winter in $\mathrm{ZX}$ ) to 98.86\% (summer in HT). The mean proportions were 52.74\%, 90.68\%, 53.72\% and $32.72 \%$ for spring to winter, respectively. Therefore, a lot of Cyanophyta characterized the phytoplankton assemblages in these three reservoirs. This was followed by the main contributors to the total biomass of the phytoplankton community, which included Chlorophyta, Xanthophyta and Bacillariophyta (Fig. 3). From spring to winter, the mean value was $1,409.44 \pm 228.51,7,436.94 \pm 1481.36,1,187.5 \pm 194.29$ and $674.72 \pm 138.55 \mathrm{ind} / \mathrm{L}$. Summer significantly differed with the other seasons $(P<0.01)$. In addition, the phytoplankton biomass in ZX was higher than that in the rest of reservoirs, except for summer, and the maximum was 13,690 $\pm 2,682.11 \mathrm{ind} / \mathrm{L}$ in HT.

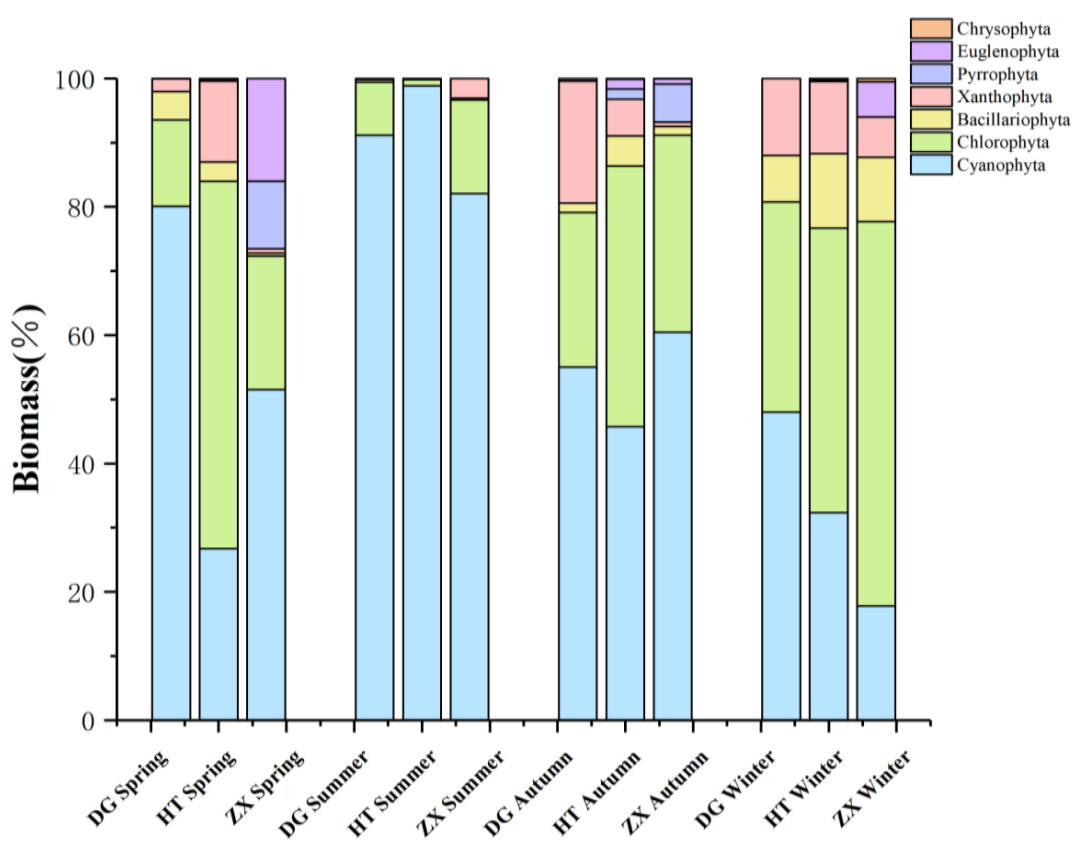

Figure 3. Seasonal biomass that comprise of the proportion of each phytoplankton group in the $D G, H T$ and ZX reservoirs from August 2017 to March 2018 


\section{Species of the diversity index}

It was essential to study the Shannon-Weiner diversity index $\left(H^{\prime}\right)$, Margalef richness index $(D)$ and Pielou evenness index $\left(J^{\prime}\right)$ to clarify the structure of the phytoplankton community. The overall pattern of the three diversity indexes represented a peak in autumn, and a minimum that was often shown in summer (Fig. 4). H', D and J' all indicated significant differences among the four seasons. The Shannon-Weiner index ranged from 0.58 (summer in DG) to 2.13 (autumn in HT), with an average of 1.50. The Margalef index ranged from 1.41 (spring in DG) to 3.46 (autumn in HT), with an average of 2.36. As for the Pielou's evenness index, this ranged from 0.16 (summer in HT) to 0.78 (winter in ZX), with an average of 0.58 .
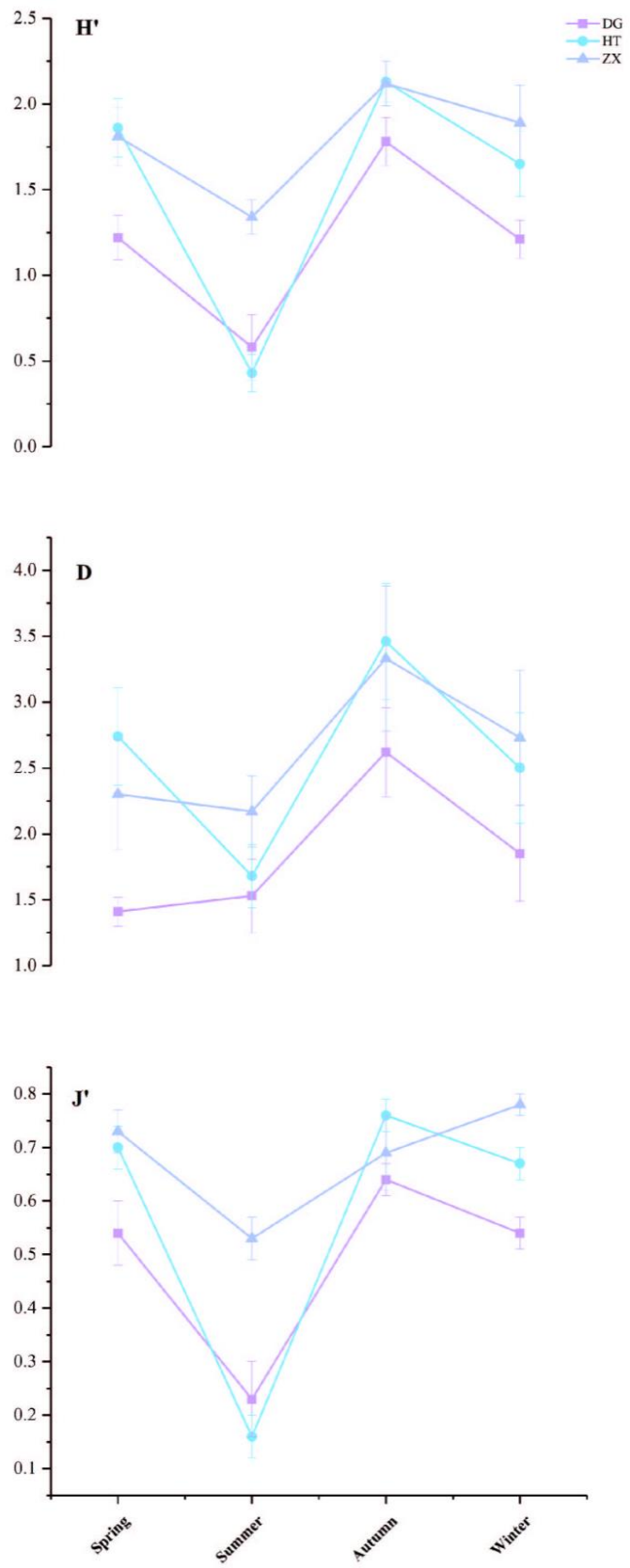

Figure 4. Seasonal H' (Shannon-Weiner index), D (Margalef index) and J' (Pielou'sindex) in the DG, HT and ZX reservoirs from August 2017 to March 2018 


\section{Phytoplankton community structure}

\section{Temporal pattern}

The result of the NMDS analysis based on the seasonal variance in dominant species biomass was presented in Figure 5. In the significant difference result for the component and biomass of dominant species between summer and others, summer was separated as an independent branch. Meanwhile, it was noteworthy that the other seasons did not gather together closely into a branch. In particular, a partial separation was observed in spring and winter, which meant that some variance in composition and abundance existed.

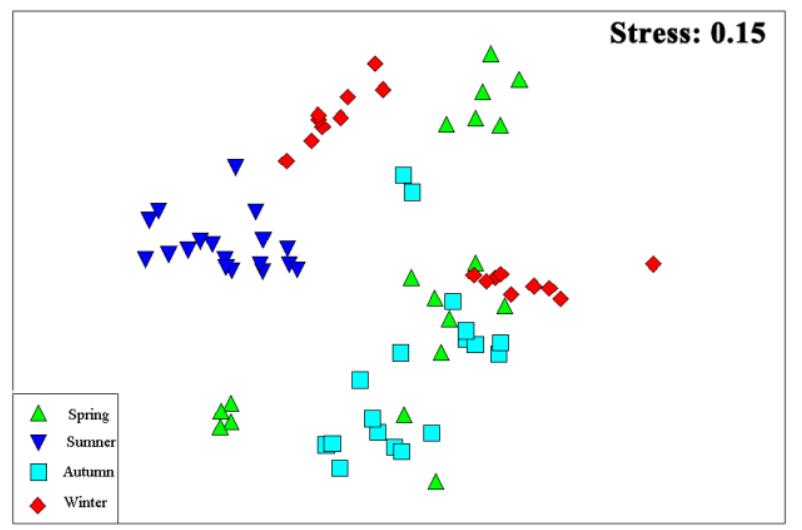

Figure 5. Temporal pattern of the phytoplankton community structure of the DG, HT and ZX reservoirs by non-metric multidimensional scaling ordination (NMDS) analysis from August 2017 to March 2018

\section{Spatial pattern}

NMDS was also conducted to determine whether the phytoplankton community structure expressed spatial differences. Different degrees of variance in phytoplankton structure among the three experimental plots was revealed from spring to winter (Fig. 6). Corresponding to the result of the temporal variance analysis, this strongly varied among the three plots in summer. In spring, DG exhibited a considerable difference with ZX and HT. However, no distinct rules were demonstrated in autumn and winter.

\section{The relationship of the phytoplankton community with environmental parameters}

The results of the CCA analysis indicated that $33.00 \%$ and $59.93 \%$ of the variance in the species-environmental relationship were carried out on the first and second axes, suggesting that there was some correlation between the environmental parameters and phytoplankton structure (Fig. 7). The Monte Carlo permutation test revealed that WT $(P=0.002), \mathrm{pH}$ $(P=0.002)$, conductivity $(P=0.002)$, dissolved oxygen $(P=0.002)$, chlorophyll-a $(P=0.002)$, TC $(P=0.022)$ and TN $(P=0.002)$ were the crucial factors that had significant impacts on phytoplankton communities, and WT explains the largest variation, which was $10.4 \%$. Along with the Spearman rank correlation analysis, $\mathrm{pH}$, WT and conductivity had a strong positively correlation with total biomass, the biomass of Cyanophyta, and the main component, Synechocystis aquatilis (R value: $\mathrm{pH}>\mathrm{WT}>$ conductivity; Table 2) However, $\mathrm{pH}$, conductivity and TC were negatively correlated with Bacillariophyta. In addition, the 
occurrence of Xanthophyta and Microcystis minutissima was positively correlated with dissolved oxygen and chlorophyll-a.

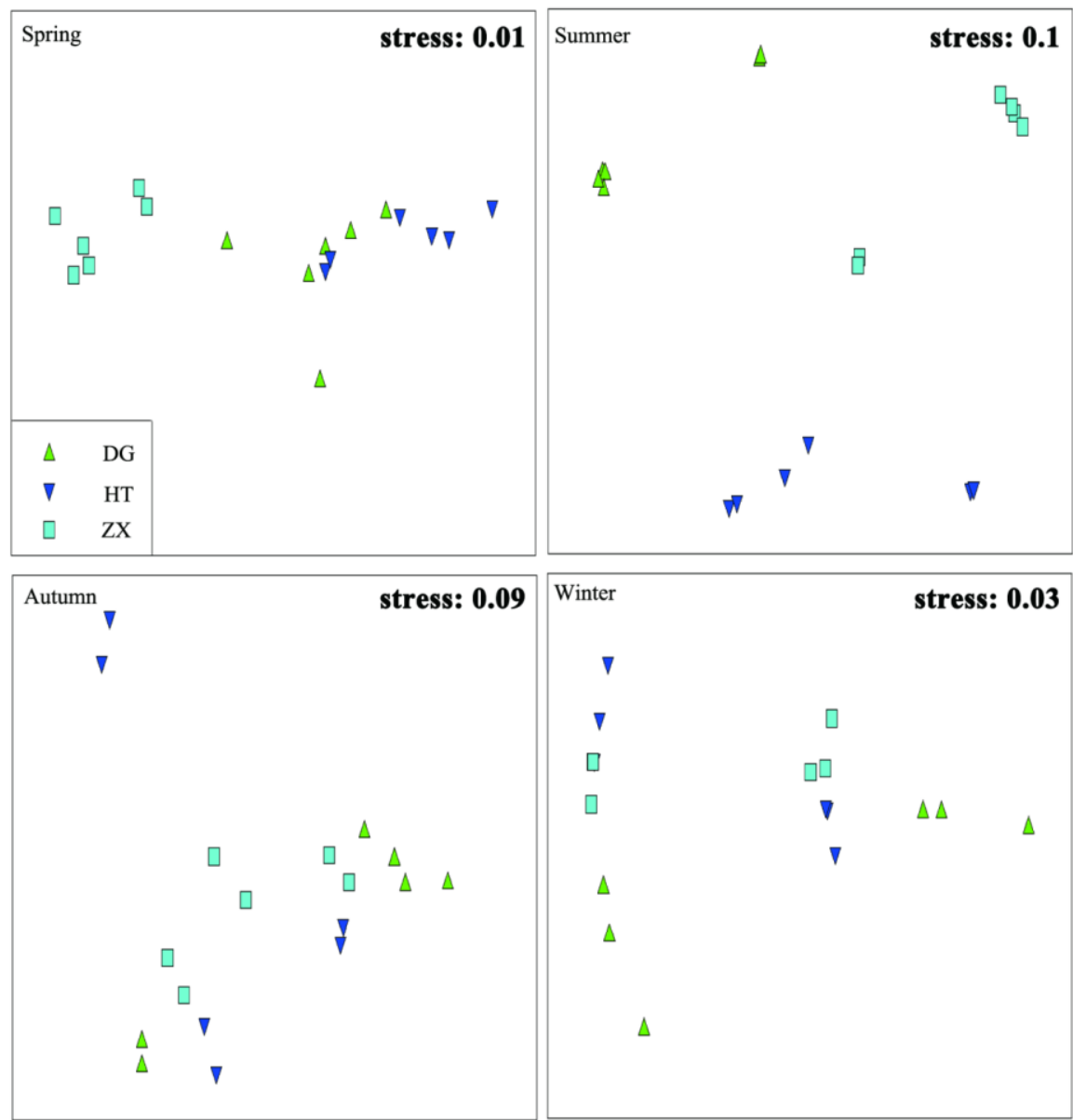

Figure 6. Spatial pattern of the phytoplankton community structure of the DG, HT and ZX reservoirs based on the non-metric multidimensional scaling ordination (NMDS) analysis from August 2017 to March 2018

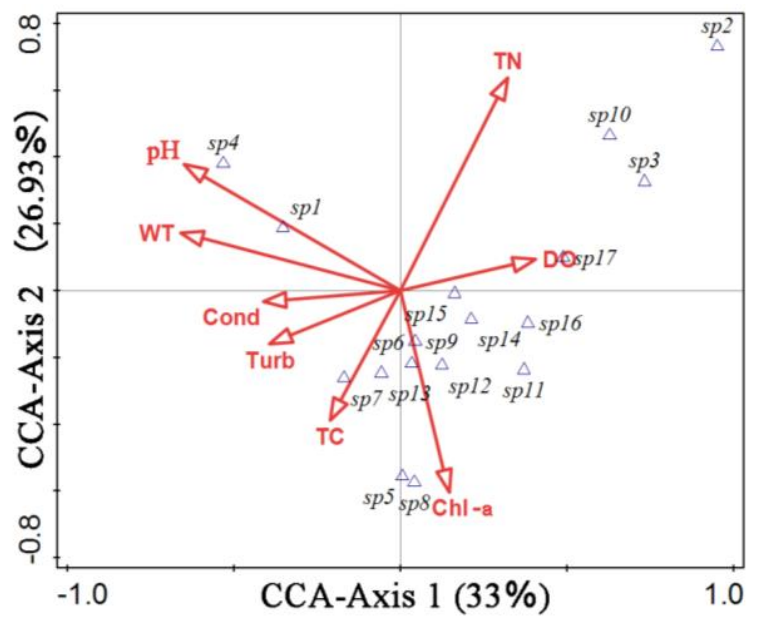

Figure 7. Relationship of phytoplankton dominant species and environmental factors in the DG, $H T$ and ZX reservoirs by Canonical Correspondence Analysis (CCA) 
Table 2. Spearman rank correlation analysis between the water factors and phytoplankton biomass

\begin{tabular}{|c|c|c|c|c|c|c|c|c|c|c|c|c|c|c|c|c|c|c|c|}
\hline & 5 & లే & $\frac{\pi}{2}$ & $\stackrel{\hat{E}}{E}$ & $\stackrel{\varrho}{0}$ & $\frac{\pi}{\frac{1}{\tau}}$ & $\underset{H}{U}$ & Z & 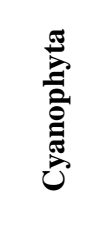 & 选 & 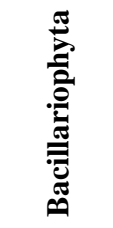 & & 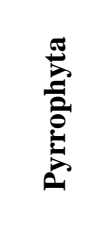 & $\begin{array}{l}\frac{9}{2} \\
\frac{E}{0} \\
\frac{0}{0} \\
\frac{0}{\overrightarrow{0}} \\
\text { 되 }\end{array}$ & 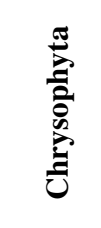 & 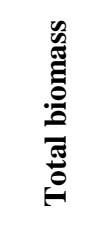 & 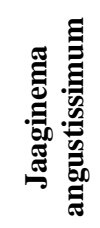 & 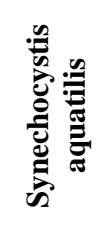 & 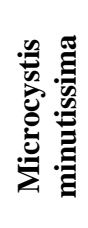 \\
\hline WT & & & & & & & & & & & & & & & & & & & \\
\hline Cond & $.835 * *$ & & & & & & & & & & & & & & & & & & \\
\hline $\mathrm{pH}$ & $.663 * *$ & $.348 * *$ & & & & & & & & & & & & & & & & & \\
\hline Turb & $.391 * *$ & $.539 * *$ & 0.056 & & & & & & & & & & & & & & & & \\
\hline DO & 0.013 & -0.135 & $.307 * *$ & $-.508 * *$ & & & & & & & & & & & & & & & \\
\hline Chl-a & $.299 *$ & $.418 * *$ & 0.143 & 0.11 & $.464 * *$ & & & & & & & & & & & & & & \\
\hline $\mathrm{TC}$ & $.363 * *$ & $.679 * *$ & -0.057 & $.620 * *$ & $-.407 * *$ & $.365 * *$ & & & & & & & & & & & & & \\
\hline $\mathrm{TN}$ & 0.068 & 0.163 & 0.119 & $.239 *$ & -0.134 & -0.106 & 0.19 & & & & & & & & & & & & \\
\hline Cyanophyta & $.556 * *$ & $.294^{*}$ & $.614 * *$ & 0.042 & 0.137 & $-.237 *$ & -0.084 & -0.093 & & & & & & & & & & & \\
\hline Chlorophyta & 0.029 & -0.053 & -0.026 & -0.107 & 0.113 & 0.081 & -0.189 & -0.077 & -0.076 & & & & & & & & & & \\
\hline Bacillariophyta & $-.251 *$ & $-.302 * *$ & -0.113 & -0.224 & 0.154 & -0.127 & $-.293 *$ & 0.117 & -0.052 & 0.192 & & & & & & & & & \\
\hline Xanthophyta & -0.039 & -0.127 & 0.057 & -0.139 & $.266 *$ & $.290 *$ & -0.12 & -0.13 & -0.101 & 0.013 & -0.056 & & & & & & & & \\
\hline Pyrrophyta & 0.003 & 0.216 & -0.166 & -0.083 & 0.04 & 0.11 & $.266^{*}$ & -0.035 & -0.11 & -0.08 & -0.125 & -0.099 & & & & & & & \\
\hline Euglenophyta & -0.116 & 0.148 & -0.208 & -0.086 & 0.117 & 0.087 & 0.072 & -0.085 & -0.148 & -0.045 & -0.154 & -0.068 & $.580 * *$ & & & & & & \\
\hline Chrysophyta & -0.113 & -0.157 & -0.102 & -0.128 & -0.081 & -0.099 & -0.037 & -0.012 & -0.069 & 0.166 & -0.029 & -0.126 & 0.143 & -0.115 & & & & & \\
\hline Total biomass & $.557 * *$ & $.285 *$ & $.613^{* *}$ & 0.021 & 0.164 & -0.22 & -0.109 & -0.105 & $.994 * *$ & 0.021 & -0.023 & -0.065 & -0.107 & -0.142 & -0.058 & & & & \\
\hline $\begin{array}{c}\text { Jaaginema } \\
\text { angustissimum }\end{array}$ & -0.109 & $|-0.106|$ & -0.023 & $-.234 *$ & $.431 * *$ & 0.049 & -0.178 & $.517 * *$ & 0 & 0.051 & $.468 * *$ & -0.08 & -0.071 & -0.097 & -0.082 & 0.007 & & & \\
\hline $\begin{array}{c}\text { Synechocystis } \\
\text { aquatilis }\end{array}$ & $.539 * *$ & $.281 *$ & $.600 * *$ & 0.079 & 0.063 & $-.270 *$ & -0.07 & -0.143 & $.988 * *$ & -0.077 & -0.085 & -0.158 & -0.103 & -0.13 & -0.06 & $.980 * *$ & -0.108 & & \\
\hline $\begin{array}{l}\text { Microcystis } \\
\text { minutissima }\end{array}$ & 0.12 & 0.041 & 0.21 & -0.172 & $.386 * *$ & $.490 * *$ & 0.038 & -0.187 & -0.054 & -0.058 & -0.043 & $.694 * *$ & 0.119 & -0.056 & 0.093 & -0.033 & -0.079 & -0.115 & \\
\hline
\end{tabular}




\section{Discussion}

\section{Effects of environmental factors on the phytoplankton community}

The objectives of the present study were to investigate the seasonal variations in phytoplankton communities, and attempt to determine the potential factors that affected the community structure. In addition, the diversity, richness and components of the structure of the phytoplankton community were predicted, and all differed from natural reservoirs without aquaculture. The findings of the present study suggest that environmental factors and anthropogenic pressure affected the phytoplankton community structure in several aspects. However, to some extent, the results in some water physico-chemical parameters and species richness were within a reasonable range of fluctuations. However, these still exhibited different succession patterns between seasons, when compared to some natural subtropical reservoirs. That is, the hypothesis was partially supported.

On one hand, the physico-chemical parameters of water had a significant impact on the structure of phytoplankton and zooplankton, such as species richness, the value of the biomass, dominant species distribution, and the composition of the community (Li et al., 2019; Horváth et al., 2017; Zhao et al., 2013). The seasonal characteristics of these ecosystems could be explained by the variability of the environment, which was due to the temporal change. The present study also revealed all water physico-chemical factors, D, H' and J', were significantly different among the four seasons. In addition, the phytoplankton community structure could display a change when the temporal changed (Fabiana Schneck et al., 2011). Furthermore, the present study demonstrated that the composition of the phytoplankton community in these three reservoirs changed between seasons. In particular, Cyanophyta dominated the phytoplankton community mostly during the experimental periods. Water temperature, $\mathrm{N}$ levels, $\mathrm{P}$ levels and dissolved oxygen could contribute to the variation of the phytoplankton community ( $\mathrm{Xu}$ et al., 2017). The present study indicated that water temperature, $\mathrm{pH}$, conductivity, dissolved oxygen, chlorophyll-a, TC and TN were the primary factors that influenced the phytoplankton community, and that water temperature contributed the most variation. Simultaneously, the Spearman rank correlation analysis also indicated that water temperature occupied the crucial factors. These results agreed with the results reported by $\mathrm{Wu}$ et al. (2012). In addition, WT, pH, conductivity and turbidity revealed similar fluctuation patterns. Furthermore, abundant data have indicated the effect of water temperature on phytoplankton growth, photosynthesis, respiration and community succession in the water ecosystem (Williamson et al., 2010; Moore, 2010; Edwards and Richardson, 2004). The optimum temperature for microalgae belonging to various groups differed, in general, and high temperature always promoted the growth of phytoplankton (Wu et al., 2013). It is not surprising that the biomass of phytoplankton generally reached a peak in summer, and decreased in spring and winter. These findings indicate that the biomass in summer considerably increased, and was far greater than that in the other seasons. The NMDS results also suggested that the phytoplankton community in summer was separated as an independent branch. Diatoms were adapted to grow in cool water, with an optimum temperature of approximately $20{ }^{\circ} \mathrm{C}$, which tended to dominate in spring. As for others, such as A. tamarense, which are not eurythermal, these reached the greatest abundance at temperatures near $18{ }^{\circ} \mathrm{C}$ (Wang et 
al., 2009). However, Cyanobacterias thrived at relatively high temperatures (approximately $28-32{ }^{\circ} \mathrm{C}$ ), according to Ribeiro et al. (2018).

The phytoplankton community was characterized a lot of Cyanobacterias, which are indicators of an ecosystem with an excess of trophic state (Kangro et al., 2005). Cyanobacteria would show significant advantages, when compared to other groups, when facing an elevation in temperature. However, even in spring and winter, Cyanobacteria continued to play an important role in the phytoplankton community, and Microcystis pallida and Microcystis pallida, Synechocystis aquatilis and Oscillatoria tenuis were the dominant species in spring and winter, respectively. Therefore, temperature was not the only affecting factors that resulted in the abundance of Cyanobacteria in these three reservoirs. In addition, other factors also accounted for the phytoplankton temporal dynamics. The CCA analysis also indicated $\mathrm{TN}$ and $\mathrm{pH}$ had a significant impact on the structure of the phytoplankton community. Nevertheless, Cyanobacteria occupied over $90 \%$ of the biomass in summer. The Spearman rank correlation analysis revealed that $\mathrm{pH}$, water temperature and conductivity had a strong positively correlation with Cyanobacteria. These results agree with other study conducted in a reservoir with cage farming (Degefu et al., 2011). Therefore, significant high biomass in summer could also be attributed to the blue-green algae outbreak. Based on previous studies on phytoplankton community structure, the rough features of Cyanobacteria could be demonstrated (Mwaura et al., 2002; Xiao et al., 2018; Smith, 1986; Sarma et al., 2005; Li et al., 2019). The Cyanobacteria exhibited better performance under high temperature, with relatively high $\mathrm{pH}$ and nutrition levels. These could shift to a position required for a suitable environment in the water column, and with a special allelopathy to dwindle other species that co-exist in the ecosystem with a possible competitive relationship. It was obvious, to some extent, that this might be attributable to the abundance of Cyanobacteria, which is advantageous of the better tolerance of grazing, homeostatic mechanism, and relatively suitable living environment for Cyanobacteria provided by these reservoirs. Meanwhile, the composition and succession rules were contrary to natural subtropical reservoirs (Yang et al., 2014). Among the four seasons, chlorophyta and cyanophyta were always the main dominant species, and the major contributors to the total biomass. However, no significant and clear phytoplankton community succession was observed. The diversity index could instruct the water trophic states, according to the study conducted by Kuang et al. (2005). These reservoirs were all in a moderately eutrophic state with the use of the method described as Kuang. That is, fish and mussels introduction might have brought some impact on the water quality, and further impacted the phytoplankton community.

\section{Effects of aquaculture on the phytoplankton community}

In addition to abiotic factors, biotic factors would affect the phytoplankton community structure, and may further bring a great impact on the water ecosystem (Reissig et al., 2006; Sarà, 2007). Integrated fish-mussel aquaculture might contribute to the variance in the composition and succession in several ways. On one hand, as far as aquatic organisms are concerned, a new predation pressure would be created, and the origin food web in the water ecosystem might be forced to change. Furthermore, the responses of the phytoplankton biomass in some groups of could be accurately predicted, based on food chain theory responses (Hansson et al., 2004). The predation pressure could be a direct or indirect major factor that affects the structure of phytoplankton, and the zooplankton community would also respond to the dynamics 
through the food web (Huston, 1979; He et al., 2017). He et al. discovered that the contribution and biomass of diatoms in the water column significantly increased due to the increasing competitiveness of microalgae with big cells caused by Crucian carp foraging activities. However, although a filter-feeder without capturing devices feeds majorly on phytoplankton and organics by forming a water flow to filter food, relying on the gill and cilium of the labial surface, cyanobacteria were a kind of inedible microalgae for these (Yan et al., 2009). Therefore, the specific selection of food by mussels has a significant impact on the food web composition, leading to a high quantity of cyanobacteria, when compared with other algae. This influenced the succession of phytoplankton communities, and possibly enhanced the similarity of species composition between seasons. Reissig et al. (2006) considered that the cyanobacteria dominated in lakes with introduced fishes. However, this phenomenon was absent in lakes without fishes. The proportion of cyanobacteria biomass in total biomass sharply plummeted, and was approximately equal to that of green algae, or even lower than that of green algae, in addition to environmental factors, and this may be correlated to the decrease in mussel population in autumn and winter. When the biomass of some microalgae occupied an absolute dominant position, this might lead to a relatively single species composition, thereby affecting the stability of the community structure and the balance of the ecosystem, while reducing the ecosystem to withstand this (Lawton, 1994). Mussels and fish polyculture had a limited effect on controlling blue-green algae blooms, but induced a decrease of some groups, which agrees to the study conducted by Soto and Mena (1999). Meanwhile, the increase in nitrogen, phosphorus concentrations and other water physico-chemical or trophic levels could be detected due to the feces, and maintenance respiration and activities. The bio-deposit degradation from aquatic organisms also may have toxic effects. On the other hand, husbandry management, such as feeding and fertilizing, were essential for some aquaculture types. Therefore, maintaining the balance and stabilization in water quality and tropical states meet greater challenges, and have an obvious impact on the microalgae community. Sarà et al. (2011) indicated that the $\mathrm{N}$ and $\mathrm{P}$ levels were continuously enhanced after the introduction of aquaculture, and approximately $34.2 .5 \%$ of the relative $\mathrm{N}$ and $\mathrm{P}$ total input was caused by tuna fish-farming activities per year. In addition, relatively low dissolved oxygen, high total chlorophyll-a, and high phytoplankton abundances, but low species richness, were recorded by Er et al. (2018). However, different aquatic organisms affected the water column differentially, the dissolved inorganic nitrogen and total phosphorus concentrations in fish farms were significantly higher than that in bivalve cultures, and the bivalve cultures exerted lighter pressure than fish cultures (Sarà, 2007; Zhang et al., 2013). These reservoirs exhibited some obvious variations in oxygen capacity and community structure, including species composition and richness, which might be due to the various management schemes, based on the NMDS analysis. The physico-chemical parameters were mostly in the favorable range for aquaculture. For example, the dissolved oxygen was suitable for the fish-mussel system, and was not in a low level, which might be a relatively low abundant biomass. For silver carp, bighead carp and mussels, the filter feeder displayed crucial roles in the reservoir ecosystem, and this might have contributed to the low abundant biomass that further decreased the oxygen expended by the respiration of micro-algae. Calcium oxide was frequently applied to increase the calcium ion concentration and regulate water quality, and these might be reasonable to understand that the water was deemed alkaline in these three reservoirs. Seasonal phytoplankton 
community dynamics would be affected from a lot of aspects, but other factors were absent from the present study, such as phosphorus levels, bacteria, zooplankton and the interaction among fish, mussel and phytoplankton.

It remains challenging to clarify the mechanism of variation in water quality and the phytoplankton community caused by the hydrological regime and man-made disturbances based on the simple investigation environment factors and community component. Hence, monitoring is fundamental to clarify the internal correlation between affecting factors and the responses, and explain the complex ecological succession from a comprehensive point. Nevertheless, the present study demonstrated the seasonal dynamic characteristics of phytoplankton and its potential risks to water ecosystems attributed to integrated fish-mussel aquaculture.

\section{Conclusion}

The total water quality parameters revealed seasonal variations and an appropriate range for aquaculture, as well as a trend of eutrophication. The phytoplankton community was characterized by high species richness and abundance, and was dominated by cyanobacteria in the three reservoirs. The biomass in summer had a significant difference, when compared to other seasons. The community structure of phytoplankton had unclear patterns due to the fish-mussel polyculture, which possibly enhanced the similarity in species composition and dominance species. In a word, environment factors, aquaculture and human disturbances have an impact on its seasonal succession and structure, in direct and indirect means.

The planning of water areas and tidal flats for aquaculture has become a fundamental strategy in ecological civilization construction at present. Fish-mussel polyculture is the main culture model, and this has been continuously generalized for pearl production, which is an important industry in aquaculture. The present study was helpful in identifying the seasonal characteristics of phytoplankton and the potential risks of fishmussel polyculture, which might bring some instructions to the better management and utilization of reservoir resources.

Acknowledgements. We are grateful to Liu Y, Luo HJ, Chen H, Li F for their assistance in the field. This work was supported by the Chinese Ministry of Science and Technology through the National Key Research and Development Program of China (2018YFD0901400); The National Natural Science Foundation of China (31660337); and Modern Agro-industry Technology Research System (CARS-49) and Modern agricultural cooperative research innovation special funds of Jiangxi(JXXTCX201602).

\section{REFERENCES}

[1] And, S. T., Songsangjinda, P. (1999): Water quality and phytoplankton communities in intensive shrimp culture ponds in Kung Krabaen Bay, Eastern Thailand. - Journal of the World Aquaculture Society 30: 36-45.

[2] Bai, Z. Y., Wang, G. L., Liu, X. J., Li, J. L. (2014): Current situation and development trend of freshwater pearl seed industry in China. - Journal of Shanghai Ocean University 23: 874-879 (in Chinese).

[3] Connell, J. H. (1978): Diversity in tropical rain forests and coral reefs. - Science 199: 1302-1310. 
[4] Danaher, J. J., Tidwell, J. H., Coyle, S. D., Dasgupta, S., Zimba, P. V. (2007): Effects of two densities of caged monosex Nile tilapia, Oreochromis niloticus, on water quality, phytoplankton populations, and production when polycultured with Macrobrachium rosenbergii in temperate ponds. - Journal of the World Aquaculture Society 38: 367-382.

[5] Degefu, F., Mengistu, S., Schagerl, M. (2011): Influence of fish cage farming on water quality and plankton in fish ponds: a case study in the Rift Valley and North Shoa reservoirs, Ethiopia. - Aquaculture 316: 129-135.

[6] Edwards, M., Richardson, A. J. (2004): Impact of climate change on marine pelagic phenology and trophic mismatch. - Nature 430: 881-884.

[7] Er, H. H., Lee, L. K., Lim, Z. F., Teng, S. T., Leaw, C. P., Lim, P. T. (2018): Responses of phytoplankton community to eutrophication in Semerak Lagoon (Malaysia). Environmental Science and Pollution Research 25: 22944-22962.

[8] Cornel, G. E., Whoriskey, F. G. (1993): The effects of rainbow trout (Oncorhynchus mykiss) cage culture on the water quality, zooplankton, benthos and sediments of Lac du Passage, Quebec. - Aquaculture 109: 101-107.

[9] Guo, L., Li, Z., Xie, P., Ni, L. (2009): Assessment effects of cage culture on nitrogen and phosphorus dynamics in relation to fallowing in a shallow lake in China. - Aquacult Int 17: 229-241.

[10] Hansson, L., Gyllstrom, M., Stahl-Delbanco, A., Svensson, M. (2004): Responses to fish predation and nutrients by plankton at different levels of taxonomic resolution. Freshwater Biol 49: 1538-1550.

[11] Hauxwell, J., Cebrián, J., Furlong, C., Valiela, I. (2001): Macroalgal canopies contribute to eelgrass (Zostera marina) decline in temperate estuarine ecosystems. - Ecology 82: 1007-1022.

[12] He, H., Hu, E., Yu, J., Luo, X., Li, K., Jeppesen, E., Liu, Z. (2017): Does turbidity induced by Carassius carassius limit phytoplankton growth? A mesocosm study. Environmental Science and Pollution Research 24: 5012-5018.

[13] He, S., Peng, K., Hong, Y., Wang, J., Sheng, J., Gu, Q. (2013): Molecular properties and immune defense of two ferritin subunits from freshwater pearl mussel, Hyriopsis schlegelii. - Fish \& Shellfish Immunology 34: 865-874.

[14] Horváth, Z., Vad, C. F., Preiler, C., Birtel, J., Matthews, B., Ptáčníková, R., Ptáčník, R. (2017): Zooplankton communities and Bythotrephes longimanus in lakes of the montane region of the northern Alps. - Inland Waters 7: 3-13.

[15] Huston, M. (1979): A general hypothesis of species diversity. - Am Nat 113: 81-101.

[16] Kangro, K., Laugaste, R., Peeter Nõges, Ott, I. (2005): Long-term changes and seasonal development of phytoplankton in a strongly stratified hypertrophic lake. - Hydrobiologia 547: 91-103.

[17] Kuang, Q., Ma, P., Hu, Z., Zhou, G. (2005): Study on the evaluation and treatment of lake eutrophication by means of algae biology. - Journal of Safety and Environment 5: 87-91 (in Chinese).

[18] Lawton, J. H. (1994): What Do Species Do in Ecosystems? - Oikos 71: 367-374.

[19] Leblanc, K., Quéguiner, B., Diaz, F., Cornet, V., Michel-Rodriguez, M., Durrieu De Madron, X., Bowler, C., Malviya, S., Thyssen, M., Grégori, G., Rembauville, M., Grosso, O., Poulain, J., de Vargas, C., Pujo-Pay, M., Conan, P. (2018): Nanoplanktonic diatoms are globally overlooked but play a role in spring blooms and carbon export. - Nature Communications 9: 953.

[20] Li, C., Feng, W., Chen, H., Li, X., Song, F., Guo, W., Giesy, J. P., Sun, F. (2019): Temporal variation in zooplankton and phytoplankton community species composition and the affecting factors in Lake Taihu-a large freshwater lake in China. - Environ Pollut 245: 1050-1057.

[21] Li, J. L. (2007): Utilization and protection of freshwater cultured pearl mussel germplasm resources. - Scientific Fish Farming 6: 1-2 (in Chinese). 
[22] Meyer, N., Bigalke, A., Kaulfuß, A., Pohnert, G. (2017): Strategies and ecological roles of algicidal bacteria. - Fems Microbiol Rev 41: 880-899.

[23] Milligan, A. J., Morel, F. M. M. (2002): A proton buffering role for silica in diatoms. Science 297: 1848-1850.

[24] Milstein, A. (1992): Ecological aspects of fish species interactions in polyculture ponds. Hydrobiologia 231: 177-186.

[25] Moore, J. W. (2010): Influence of temperature, photoperiod and trophic conditions on the seasonal cycles of phytoplankton and zooplankton in two deep subarctic lakes of northern Canada. - Int Rev Hydrobiol 66: 745-770.

[26] Mwaura, F., Mavuti, K. M., Wamicha, W. N. (2002): Biodiversity characteristics of small high-altitude tropical man-made reservoirs in the eastern Rift valley, Kenya. Lakes and reservoirs. - Res. Management 7: 1-12.

[27] Neori, A., Chopin, T., Troell, M., Buschmann, A. H., Kraemer, G. P., Halling, C., Shpigel, M., Yarish, C. (2004): Integrated aquaculture: rationale, evolution and state of the art emphasizing seaweed biofiltration in modern mariculture. - Aquaculture 231: 361391.

[28] Peng, K., Wang, J., Sheng, J., Zeng, L., Hong, Y. (2012): Molecular characterization and immune analysis of a defensin from freshwater pearl mussel, Hyriopsis schlegelii. Aquaculture 334-337: 45-50.

[29] Reissig, M., Trochine, C., Queimaliños, C., Balseiro, E., Modenutti, B. (2006): Impact of fish introduction on planktonic food webs in lakes of the Patagonian Plateau. - Biol Conserv 132: 437-447.

[30] Ribeiro, K. F., Duarte, L., Crossetti, L. O. (2018): Everything is not everywhere: a tale on the biogeography of cyanobacteria. - Hydrobiologia 820: 23-48.

[31] Sarà, G. (2007): Ecological effects of aquaculture on living and non-living suspended fractions of the water column: a meta-analysis. - Water Res 41: 3187-3200.

[32] Sarà, G., Lo Martire, M., Sanfilippo, M., Pulicanò, G., Cortese, G., Mazzola, A., Manganaro, A., Pusceddu, A. (2011): Impacts of marine aquaculture at large spatial scales: evidences from $\mathrm{N}$ and $\mathrm{P}$ catchment loading and phytoplankton biomass. - Mar Environ Res 71: 317-324.

[33] Sarma, S. S. S., Nandini, S., et al. (2005): Life history strategies of cladocerans: comparisons of tropical and temperature taxa. - Hydrobiologia 542: 315-334.

[34] Schneck, F., Schwarzbold, A., Rodrgues, S. C., Melo, A. S. (2011): Environmental variability drives phytoplankton assemblage persistence in a subtropical reservoir. Austral Ecol 36: 839-848.

[35] Schneider, O., Sereti, V., Eding, E. H., Verreth, J. A. J. (2005): Analysis of nutrient flows in integrated intensive aquaculture systems. - Aquacult. Eng 32: 379-401.

[36] Smith, V. H. (1986): Light and nutrient effects on the relative biomass of blue-green in lake phytoplankton. - Can. J. Fish. Aquat. Sci 43: 148-153.

[37] Soto, D., Mena, G. (1999): Filter feeding by the freshwater mussel, Diplodon chilensis, as a biocontrol of salmon farming eutrophication. - Aquaculture 171: 65-81.

[38] Tang, J. Y., Dai, Y. X., Wang, Y., Qin, J. G., Su, S. S., Li, Y. M. (2015): Optimization of fish to mussel stocking ratio: development of a state-of-art pearl production mode through fish-mussel integration. - Aquacult Eng 66: 11-16.

[39] Troell, M., Halling, C., Neori, A., Chopin, T., Buschmann, A. H., Kautsky, N., Yarish, C. (2003): Integrated mariculture: asking the right questions. - Aquaculture 226: 69-90.

[40] Wang, Y., Wang, W. L., Qin, J. G., Wang, X. D., Zhu, S. B. (2009): Effects of integrated combination and quicklime supplementation on growth and pearl yield of freshwater pearl mussel, Hyriopsis cumingii (Lea, 1852). - Aquat Res 40: 1634-1641.

[41] Wang, Z., Zhao, J., Zhang, Y., Cao, Y. (2009): Phytoplankton community structure and environmental parameters in aquaculture areas of Daya Bay, South China Sea. - J Environ Sci (China) 21: 1268-1275. 
[42] Williamson, C. E., Salm, C., Cooke, S. L., Saros, J. E. (2010): Erratum to: how do UV radiation, temperature, and zooplankton influence the dynamics of alpine phytoplankton communities? - Hydrobiologia 652: 395-396.

[43] Wu, W. J., Yang, K., Wang, Z. C., Li, G. B., Liu, Y. D. (2012): Phytoplankton community structure and seasonal succession in Yudong reservoir, Yunnan-Guizhou plateau. - Journal of Hydroecology 33: 69-75 (in Chinese).

[44] Wu, Z. S., Cai, Y. J., Liu, X., Xu, C. P., Chen, Y. W., Zhang, L. (2013): Temporal and spatial variability of phytoplankton in Lake Poyang: the largest freshwater lake in China. - J Great Lakes Res 39: 476-483.

[45] Xiao, M., Li, M., Reynolds, C. S. (2018): Colony formation in the cyanobacterium Microcystis. - Biol Rev 93: 1399-1420.

[46] Xu, Y., Li, A. J., Qin, J., Li, Q., Ho, J. G., Li, H. (2017): Seasonal patterns of water quality and phytoplankton dynamics in surface waters in Guangzhou and Foshan, China. - Sci Total Environ 590-591: 361-369.

[47] Yan, L., Zhang, G., Liu, Q., Li, J. (2009): Optimization of culturing the freshwater pearl mussels, Hyriopsis cumingii with filter feeding Chinese carps (bighead carp and silver carp) by orthogonal array design. - Aquaculture 292: 60-66.

[48] Yang, L. J., Yu, P. F., Zhu, J. Q., Xu, Z., Lv, G. H., Jin, C. H. (2014): Phytoplankton community structure and its influencing factors in Hengshan reservoir, Zhejiang province. - Chinese Journal of Applied Ecology 25: 569-576 (in Chinese).

[49] Zhang, X., Huang, X., Huang, L. (2013): Phytoplankton community structure shaped by key environmental factors in fish and shellfish farms in Daya Bay, South China. - Aquat Ecosyst Health 16: 300-310.

[50] Zhang, Z. S., Huang, X. F. (1991): Research Methods on Freshwater Plankton. - Science Press, Beijing (in Chinese).

[51] Zhao, Z., Mi, T., Xia, L., Yan, W., Jiang, Y., Gao, Y. (2013): Understanding the patterns and mechanisms of urban water ecosystem degradation: phytoplankton community structure and water quality in the Qinhuai River, Nanjing City, China. - Environ Sci Pollut R 20: 5003-5012.

[52] Zheng, X., Zhang, D., Qin, J., Wang, Y. (2018): The effect of C/N ratio on bacterial community and water quality in a mussel-fish integrated system. - Aquac Res 49: 16991708 .

\section{APPENDIX}

Table A1. Collected species list of phytoplankton in the three reservoirs from August 2017 to March 2018

\begin{tabular}{|c|c|c|c|c|c|c|c|c|c|c|c|c|}
\hline \multirow{2}{*}{ Phytoplankton species } & \multicolumn{3}{|c|}{ Spring } & \multicolumn{3}{|c|}{ Summer } & \multicolumn{3}{|c|}{ Autumn } & \multicolumn{3}{|c|}{ Winter } \\
\hline & DG & HT & $\mathbf{Z X}$ & DG & HT & $\mathbf{Z X}$ & DG & HT & $\mathbf{Z X}$ & DG & HT & $\mathbf{Z X}$ \\
\hline Cyanophyta & & & & & & & & & & & & \\
\hline Jaaginema angustissimum & $* *$ & & & & & & & & & & & \\
\hline Microcystis pallida & $*$ & $*$ & $* *$ & $*$ & $* *$ & $* *$ & $*$ & $*$ & & & & \\
\hline Oscillatoria granulata & $*$ & & * & & & & & $*$ & $*$ & & & \\
\hline Chroococcus limneticus & $*$ & & & & $*$ & $*$ & $*$ & $*$ & $*$ & $*$ & $*$ & $*$ \\
\hline Anabaena cylindrica & $*$ & $*$ & & $*$ & $*$ & $*$ & $*$ & $*$ & $*$ & $*$ & $*$ & $*$ \\
\hline Nostoc rivulare & $*$ & $*$ & $*$ & $*$ & $*$ & $*$ & & $*$ & $*$ & $*$ & $*$ & \\
\hline Raphidiopsis curvata & $*$ & & & $*$ & $*$ & & & & & & $*$ & \\
\hline Oscillatoria acuminata & * & & & & & & & & & & & \\
\hline Geitlerinema acutissimum & $*$ & & & $*$ & $*$ & $*$ & & & $*$ & & & \\
\hline Dactylococcopsis acicularis & $*$ & & & $*$ & $*$ & $*$ & & $*$ & & $*$ & $*$ & \\
\hline Leptolyngyya valderiana & $*$ & & & & & & & & & & & \\
\hline Synechocystis millei & & * & $*$ & & & & & & & & & \\
\hline
\end{tabular}




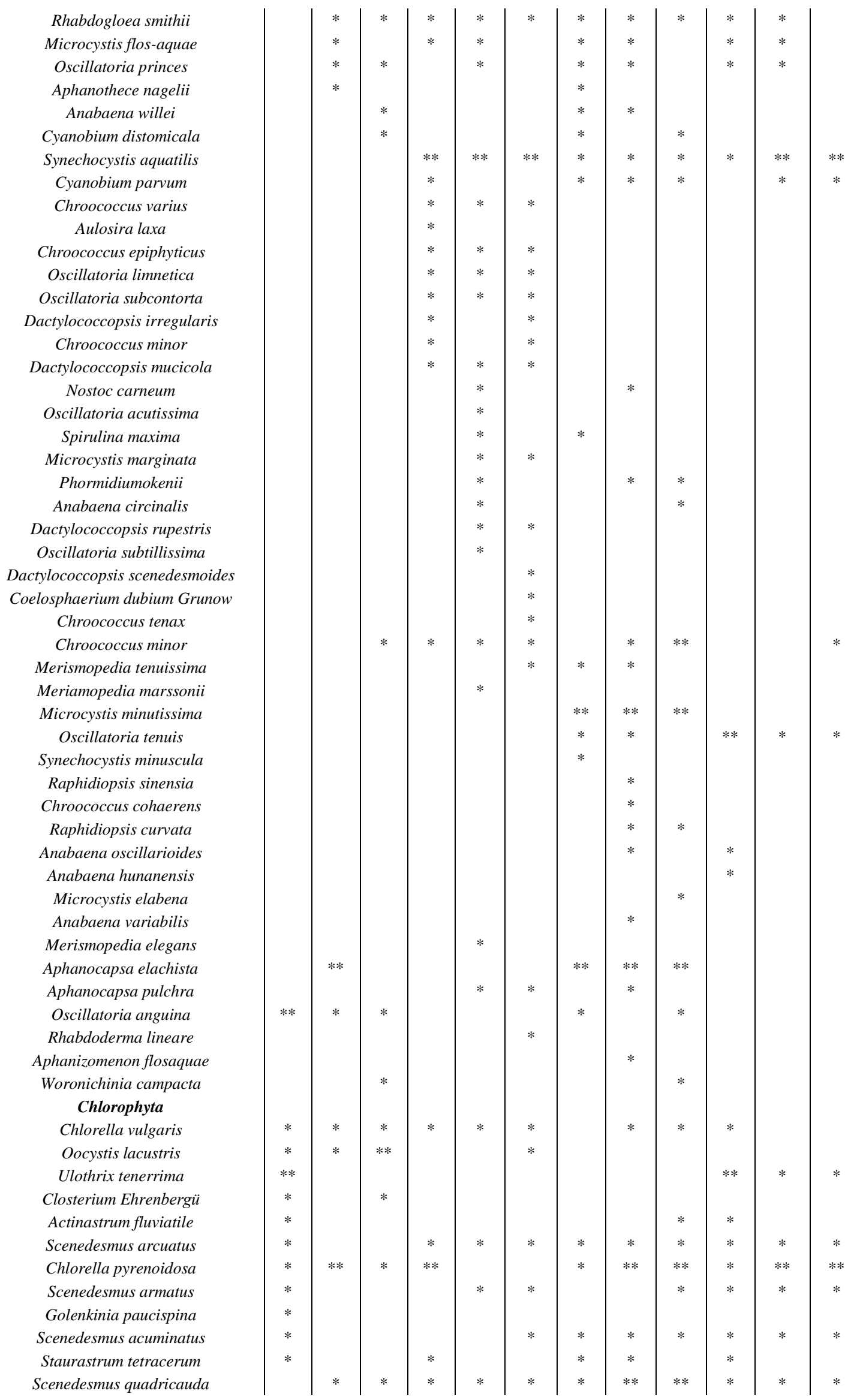


Schroederia nitzschioides

Scenedesmus bicaudatus

Microspora stagnorum

Pediastrum simplex var. duodenarium

Scenedesmus bijuga

Ankistrodesmus acicularis

Ankistrodesmus angustus

Schroederia setigera

Gonatozygon monotaenium

Scenedesmus ovalternus

S.armatus var.boglariensis f.bicaudatus

Chloromonas mikroneusa

Ulothrix moniliformis

Pediastrum duplex var.gracillimum

Closteriopsis longissima

Ankistrodesmus falcatus var.mirabilis

Raphidonema longiseta

Treubaria crassispina

Eudorina elegans

Pediastrum biradiatum

T. trigonum var.gracile

Westellopsis linearis

Staurastrum pingue

Staurastrum gracile

Gonatozygon kinahani

Ulothrix variabilis

Chodatella subsalsa

Staurastrum aristiferum

Cosmarium botrytis

Staurastrum sexangulare

Staurastrum pseudotetracerum

Staurastrum retusum

Staurastrum willsii Turn

Scenedesmus dimorphus

Staurastrum manfeldtii Delp.

Crucigenia rectangularis

Tetraëdron regulare var. incus

Cosmarium nasutum

Hormidium Kuetzing

Chlorella ellipsoidea

Spondylostium planum

S.armatus var.boglariensis f.bicaudatus

Schroederia spiralis

Ankistrodesmus falcatus

Pediastrum biradiatum

Planctonema lauterbornü

Chlorococcum sp.

Quadrigula chodatii

Provasolialla cylintrica

Tetraëdron tumidulum

Tetrastrum elega

Golenkinia radiata

Tetrallantos lagerkeim

Raphidonema longiseta

Scenedesmus abundans var. asymmetrica

Staurastrum planctonicum

Staurastrum margaritaceum

Scenedesmus acutiformis

Tetraëdron trilobulatum

Tetraëdron regulare var. torsum

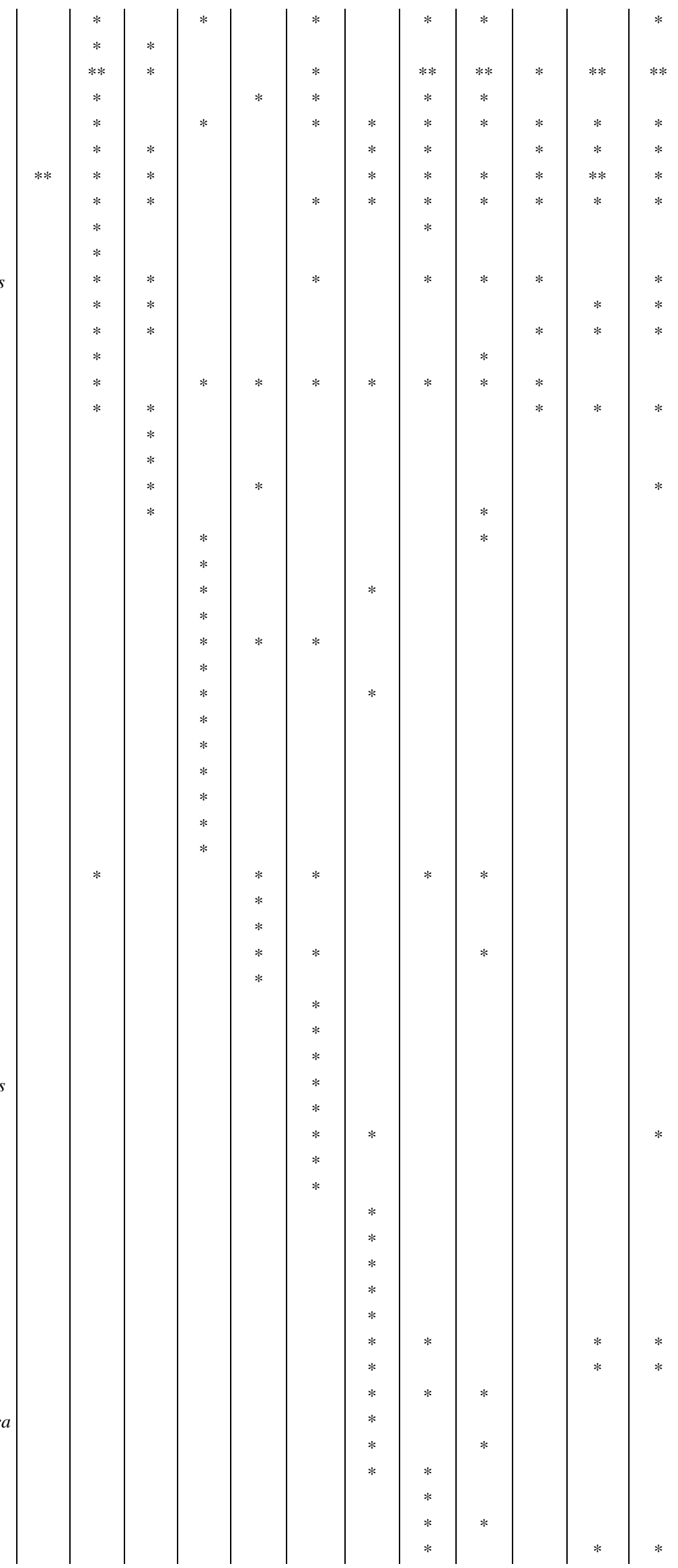

APPLIED ECOLOGY AND ENVIRONMENTAL RESEARCH 18(2):3387-3408.

http://www.aloki.hu • ISSN 15891623 (Print) • ISSN 17850037 (Online)

DOI: http://dx.doi.org/10.15666/aeer/1802_33873408

(c) 2020, ALÖKI Kft., Budapest, Hungary 


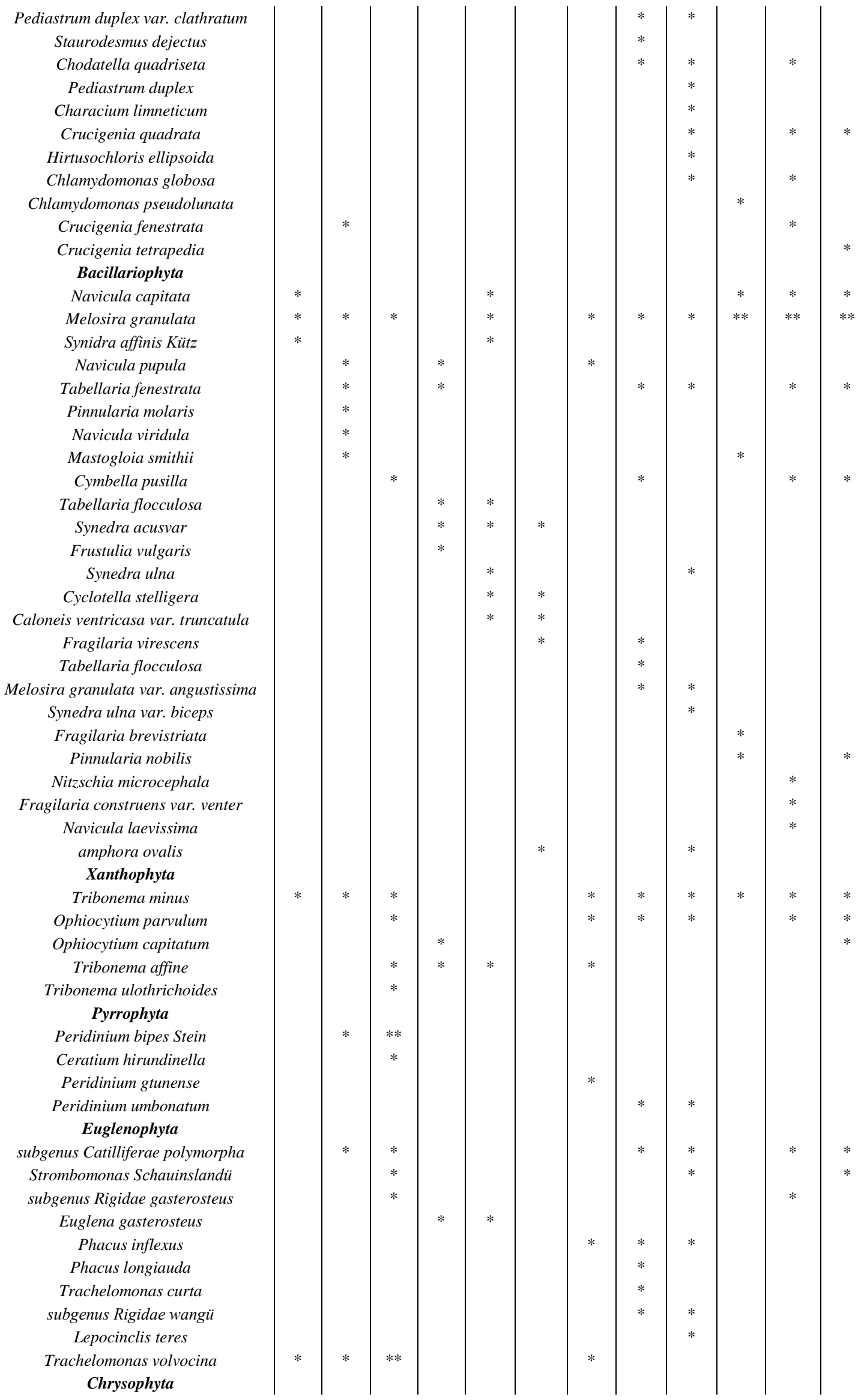




\begin{tabular}{c|c|c|c|c|c|c|c|c|}
$\begin{array}{c}\text { Chrysamoeba radians } \\
\text { Epipyxis utriculus } \\
\text { Dinobryon cylindricum }\end{array}$ & & & & & & & $*$ & $*$ \\
\hline
\end{tabular}

*: appeared;**: dominant species (dominance index >0.02)

APPLIED ECOLOGY AND ENVIRONMENTAL RESEARCH 18(2):3387-3408.

http://www.aloki.hu • ISSN 15891623 (Print) • ISSN 17850037 (Online)

DOI: http://dx.doi.org/10.15666/aeer/1802_33873408

(c) 2020, ALÖKI Kft., Budapest, Hungary 